\title{
REVIEW
}

\section{Protective mechanical ventilation in the non-injured lung: review and meta-analysis}

\author{
Yuda Sutherasan', Maria Vargas², Paolo Pelosi3* \\ This article is one of ten reviews selected from the Annual Update in Intensive Care and Emergency Medicine 2014 and co-published as a series \\ in Critical Care. Other articles in the series can be found online at http://ccforum.com/series/annualupdate2014. Further information about the \\ Annual Update in Intensive Care and Emergency Medicine is available from http://www.springer.com/series/8901.
}

\begin{abstract}
Introduction
Acute respiratory distress syndrome (ARDS) is one of the main causes of mortality in critically ill patients. Injured lungs can be protected by optimum mechanical ventilator settings, using low tidal volume $\left(\mathrm{V}_{\mathrm{T}}\right)$ values and higher positive-end expiratory pressure (PEEP); the benefits of this protective strategy on outcomes have been confirmed in several prospective randomized controlled trials (RCTs). The question is whether healthy lungs need specific protective ventilatory settings when they are at risk of injury. We performed a systematic review of the scientific literature and a meta-analysis regarding the rationale of applying protective ventilatory strategies in patients at risk of ARDS in the perioperative period and in the intensive care unit (ICU).
\end{abstract}

\section{Mechanism of ventilator-induced lung injury in healthy lungs}

Several studies have reported the multiple hit theory as the main cause of ARDS in previously healthy lungs (transfusion, cardiopulmonary bypass [CPB], sepsis etc.). Recently, many investigators have reported that, in healthy lungs, mechanical ventilation can aggravate the 'one hit' ventilator-induced lung injury (VILI), even when using the least injurious settings.

The pathophysiologic principles of VILI are complex and characterized by different overlapping interactions. These interactions include: (a) high $\mathrm{V}_{\mathrm{T}}$ causing over distension; (b) cyclic closing and opening of peripheral airways during tidal breath resulting in damage of both the bronchiolar epithelium and the parenchyma (lung strain), mainly at the alveolar-bronchiolar junctions; (c) lung stress by increased transpulmonary pressure (the

*Correspondence: ppelosi@hotmail.com

${ }^{3}$ AOU IRCCS San Martino-IST, Department of Surgical Sciences and Integrated Diagnostics, University of Genoa, Genoa, Italy

Full list of author information is available at the end of the article difference between alveolar and pleural pressure); (d) low lung volume associated with recruitment and de-recruitment of unstable lung units (atelectrauma); (e) inactivation of surfactant by large alveolar surface area oscillations associated with surfactant aggregate conversion, which increases surface tension [1]; (f) local and systemic release of lung-borne inflammatory mediators, namely biotrauma [2].

Recent experimental and clinical studies have demonstrated two main mechanisms leading to VILI: First, direct trauma to the cell promoting releasing of cytokines to the alveolar space and the circulation; second, the so-called 'mechanotransduction' mechanism. Cyclic stretch during mechanical ventilation stimulates alveolar epithelial and vascular endothelial cells through mechano-sensitive membrane-associated protein and ion channels [3]. High $\mathrm{V}_{\mathrm{T}}$ ventilation led to an increase in expression of intrapulmonary tumor necrosis factor (TNF) $-\alpha$ and macrophage inflammatory protein- 2 in mice without previous lung injury [4] and recruited leukocytes to endothelial cells [3]. Tissue deformation activates nuclear factor-kappa B (NF-кB) signaling consequent to the production of interleukin (IL)-6, IL-8, IL-1 $\beta$ and TNF- $\alpha$ [3]. The cellular necrosis is associated with an inflammatory response in surrounding lung tissue [3].

Mechanotransduction is the conversion of mechanical stimuli to a biochemical response when alveolar epithelium or vascular endothelium is stretched during mechanical ventilation. The stimulus causes expansion of the plasma membrane and triggers cellular signaling via various inflammatory mediators influencing pulmonary and systemic cell dysfunction [3]. A high level of mechanical stretch is associated with increased epithelial cell necrosis, decreased apoptosis and increased IL-8 level [3]. Extracellular matrix (ECM), a three-dimensional fiber mesh, is composed of collagen, elastin, glycosaminoglycans (GAGs) and proteoglycans. The ECM represents 
the biomechanical behavior of the lung and plays a role in stabilizing lung matrix and fluid content. Mechanotransduction causes the mechanical force on ECM that causes the lung strain (the ratio between $V_{T}$ and functional residual capacity $[\mathrm{FRC}]$ ). High $\mathrm{V}_{\mathrm{T}}$ ventilation causes ECM remodeling, influenced by the airway pressure gradient and the pleural pressure gradient [2], [5].

In animal models, VILI, defined by lung edema formation, develops when lung strain is greater than 1.5-2 [6]. Cyclic mechanical stress causes release and activation of matrix metalloproteinase (MMP). MMP plays an important role in regulating ECM remodeling and VILI. Lung strain also leads to modification of proteoglycan and GAGs. The fragmentation of GAGs may affect the development of the inflammatory response by interacting with various types of chemokine and acting as ligands for Toll-like receptors [5], [7]. In addition, the ECM has been demonstrated to be the signal of matrikines requiring proteolytic breakdown. Mechanical strain induces ECM breakdown [5].

During the perioperative period, general anesthesia and deep sedation with or without muscle paralysis markedly affect lung structure by reducing the tone of respiratory muscles and altering diaphragmatic position [8]. A direct effect of anesthetics on pulmonary surfactant, as well as the weight of the heart and greater intra-abdominal pressure in the supine position, promotes collapse of dependent lung regions and partial collapse of mid-pulmonary regions as a consequence of the reduction in end-expiratory lung volume. These alterations promote: (a) increase in lung elastance; (b) increase in lung resistance; and (c) impairment in gas exchange. The morphological alterations of the lungs are sustained at least for the first 24-72 hours postoperatively, particularly in patients undergoing high-risk surgery. In addition these alterations facilitate rapid shallow breathing and increased work of breathing as well as impaired gas-exchange [9] (Figure 1).

\section{Protective ventilation strategies}

The previously mentioned mechanisms have encouraged intensive care physicians and anesthesiologists to consider 'protective ventilation strategies' in vulnerable noninjured lungs, which use physiologic low $\mathrm{V}_{\mathrm{T}}$ values, moderate to high levels of PEEP and/or recruitment maneuvers.

\section{Tidal volume, positive end-expiratory pressure and recruitment maneuvers \\ In surgery}

A recent large prospective cohort study conducted in different types of surgery demonstrated that the incidence of in-hospital mortality was about as high as the incidence of postoperative pulmonary complications which were associated with prolonged hospital stays [10]. Historically, use of large $\mathrm{V}_{\mathrm{T}}(10-15 \mathrm{ml} / \mathrm{kg})$ was advocated during the perioperative period to prevent impaired oxygenation and re-open collapsed lung units [11]. Nowadays, lung protective ventilation has become the standard of care in patients with ARDS. Secondary analysis of the ARDS network trial database revealed that the reduction in $\mathrm{V}_{\mathrm{T}}$ from 12 to $6 \mathrm{ml} / \mathrm{kg}$ predicted body weight (PBW) yielded benefit, regardless of the level of plateau pressure [12]. Over the last few decades, clinicians have tended to decrease $\mathrm{V}_{\mathrm{T}}$ from $8.8 \mathrm{ml} / \mathrm{kg}$ actual body weight (ABW) to $6.9 \mathrm{ml} / \mathrm{kg} \mathrm{ABW}$ in critically ill patients [13].

Applying a PEEP $\geq 8 \mathrm{~cm} \mathrm{H}_{2} \mathrm{O}$ and using recruitment maneuvers may increase end-expiratory lung volume (EELV) beyond airway closure, certainly preventing atelectasis. However, the adverse effect of PEEP and recruitment maneuvers is a possible reduction in right ventricular (RV) preload and an increase in RV afterload. These consequences may lead to lower stroke volume and potentially became problematic during surgery. Therefore, the role of low $V_{T}$ ventilation and moderate to high PEEP levels with recruitment maneuvers in previously non-injured lungs is still controversial during surgery.

In terms of lung mechanics and gas exchange, during cardiac surgery protective ventilation with a $\mathrm{V}_{\mathrm{T}}$ of $6 \mathrm{ml} /$ $\mathrm{kg}$ and PEEP $5 \mathrm{~cm} \mathrm{H}_{2} \mathrm{O}$ can improve lung mechanics and prevent postoperative shunting compared to conventional or standard ventilation with $\mathrm{V}_{\mathrm{T}}$ of $12 \mathrm{ml} / \mathrm{kg}$ and PEEP $5 \mathrm{~cm} \mathrm{H}_{2} \mathrm{O}$ [14].

In patients undergoing $\mathrm{CPB}$ surgery, Koner et al. found no differences in plasma levels of TNF- $\alpha$ or IL- 6 in patients ventilated with $V_{T}$ of $6 \mathrm{ml} / \mathrm{kg}$ plus PEEP $5 \mathrm{~cm} \mathrm{H}_{2} \mathrm{O}$, with $\mathrm{V}_{\mathrm{T}} 10 \mathrm{ml} / \mathrm{kg}$ plus PEEP $5 \mathrm{~cm} \mathrm{H}_{2} \mathrm{O}$ or with $\mathrm{V}_{\mathrm{T}} 10 \mathrm{ml} / \mathrm{kg}$ but zero end-expiratory pressure (ZEEP) [15]. Wrigge et al. also reported that ventilation with $\mathrm{V}_{\mathrm{T}}$ of $6 \mathrm{ml} / \mathrm{kg}$ or with $12 \mathrm{ml} / \mathrm{kg}$ for 6 hours did not affect serum TNF- $\alpha$, IL- 6 , or IL-8 concentrations in CPB surgery; only bronchoalveolar lavage (BAL) fluid TNF- $\alpha$ levels were significantly higher in the higher $V_{T}$ group [16]. In contrast, Zupancich et al. showed that serum and BAL fluid IL-6 and IL-8 levels were elevated in a conventional ventilation group compared to a protective ventilation group after 6 hours of ventilation [17].

During major thoracic and abdominal surgery, there was no difference in the time course of tracheal aspirate and plasma TNF- $\alpha$, IL-1, IL-6, IL-8, IL-12, or IL-10 in patients receiving conventional ventilation $\left(\mathrm{V}_{\mathrm{T}} 12-15 \mathrm{ml} /\right.$ $\mathrm{kg}$ ideal body weight [IBW] and PEEP $\left.0 \mathrm{~cm} \mathrm{H}_{2} \mathrm{O}\right)$ and those receiving protective ventilation $\left(\mathrm{V}_{\mathrm{T}} 6 \mathrm{ml} / \mathrm{kg} \mathrm{IBW}\right.$ and PEEP $10 \mathrm{~cm} \mathrm{H}_{2} \mathrm{O}$ ) [18]. In abdominal surgery, Wolthuis et al. demonstrated attenuation of pulmonary IL-8, myeloperoxidase and elastase in a protective ventilation group [19]. In terms of clinical outcomes, 


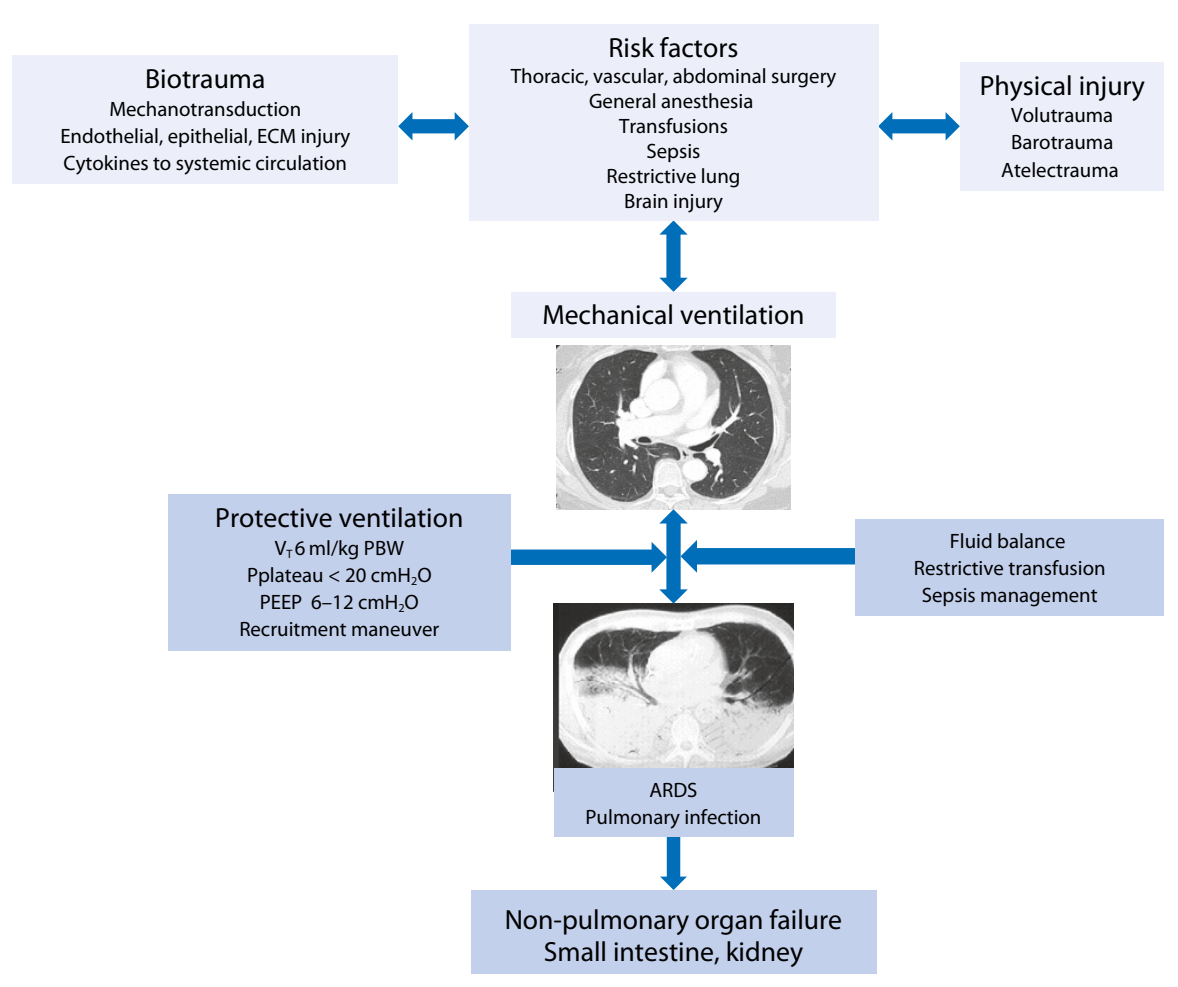

Figure 1. Pathophysiology of ventilator-induced lung injury (VILI) in non-injured lungs and the lung-protective ventilatory approach. $V_{\text {: }}$ tidal volume; PBW: predicted body weight; PEEP: positive end-expiratory pressure; ARDS: acute respiratory distress syndrome; ECM: extracellular matrix.

elderly patients undergoing major abdominal surgery ventilated with $6 \mathrm{ml} / \mathrm{kg} \mathrm{PBW}, 12 \mathrm{~cm} \mathrm{H}_{2} \mathrm{O}$ PEEP and receiving a recruitment maneuver by sequentially increasing PEEP in 3 steps to $20 \mathrm{~cm} \mathrm{H}_{2} \mathrm{O}$ had no hemodynamic effects and achieved better intraoperative $\mathrm{PaO}_{2}$ and dynamic lung compliance compared with patients receiving conventional ventilation with $V_{T}$ $10 \mathrm{ml} / \mathrm{kg}$ without PEEP and recruitment maneuvers. However, this study showed no differences in IL-6 and IL-8 levels [20].

In a prospective study of 3434 cardiac surgery patients, only $21 \%$ of patients received $\mathrm{V}_{\mathrm{T}}<10 \mathrm{ml} / \mathrm{kg} \mathrm{PBW} ; \mathrm{V}_{\mathrm{T}}$ values of more than $10 \mathrm{ml} / \mathrm{kg}$ PBW were an independent risk factor for multiple organ failure [21]. Obesity, female gender and short height are risk factors for receiving $\mathrm{V}_{\mathrm{T}}$ of more than $10 \mathrm{ml} / \mathrm{kg}$ [22].

Treschan et al. demonstrated that applying $\mathrm{V}_{\mathrm{T}}$ of $6 \mathrm{ml} /$ kg PBW during major abdominal surgery did not attenuate postoperative lung function impairment compared to $\mathrm{V}_{\mathrm{T}}$ values of $12 \mathrm{ml} / \mathrm{kg} \mathrm{PBW}$ with the same PEEP level of $5 \mathrm{~cm} \mathrm{H}_{2} \mathrm{O}$ [23]. However, Severgnini et al. showed that compared to conventional ventilation $\left(\mathrm{V}_{\mathrm{T}}\right.$ $9 \mathrm{ml} / \mathrm{kg}$ IBW without PEEP), application of protective ventilation during abdominal surgery lasting more than 2 hours $\left(\mathrm{V}_{\mathrm{T}} 7 \mathrm{ml} / \mathrm{kg}\right.$ IBW, PEEP $10 \mathrm{~cm} \mathrm{H} \mathrm{H}_{2} \mathrm{O}$, and recruitment maneuver) improved pulmonary function tests for up to 5 days, with reduced modified Clinical Pulmonary Infection Scores (mCPIS), lower rates of postoperative pulmonary complications, and better oxygenation [24]. A study conducted by Futier et al. (IMPROVE study) emphasizes the benefits of low $\mathrm{V}_{\mathrm{T}}$ with PEEP and recruitment maneuver. This large RCT demonstrated that major pulmonary and extrapulmonary complications within 7 days after major abdominal surgery occurred in 21 patients $(10.5 \%)$ in the protective ventilation group $\left(\mathrm{V}_{\mathrm{T}} 6-8 \mathrm{ml} / \mathrm{kg}\right.$ PBW, PEEP 6-8 cm H $\mathrm{H}_{2} \mathrm{O}$ and recruitment maneuver) compared with 55 patients $(27.5 \%)$ in the conventional ventilation group $\left(\mathrm{V}_{\mathrm{T}} 10-\right.$ $12 \mathrm{ml} / \mathrm{kg}$ PBW without PEEP); furthermore, patients in the protective ventilation group had shorter lengths of hospital stay than those in the conventional group [25].

Higher $V_{T}$ ventilation seems to be an inflammatory stimulus for the lungs. However, as shown in the studies mentioned earlier, in terms of resultant local and systemic inflammatory responses processes, results are still debated [15], [16], [18], [26]. Application of lower $\mathrm{V}_{\mathrm{T}}$ is challenging because it can possibly increase the risk of atelectasis. Nevertheless, Cai et al. showed that applying ventilation with $\mathrm{V}_{\mathrm{T}}$ of $6 \mathrm{ml} / \mathrm{kg}$ alone was associated with no difference in the amount of atelectasis compared to 
Table 1. Characteristics and impact of protective ventilation in surgical patients

\begin{tabular}{|c|c|c|c|c|c|c|c|c|}
\hline \multirow[b]{2}{*}{$\begin{array}{l}\text { First author, } \\
\text { Year [Ref] }\end{array}$} & \multirow[b]{2}{*}{ No } & \multirow[b]{2}{*}{ Design } & \multirow[b]{2}{*}{$\begin{array}{l}\text { Patient } \\
\text { population }\end{array}$} & \multicolumn{2}{|c|}{ Protective ventilation } & \multicolumn{2}{|c|}{ Standard ventilation } & \multirow[b]{2}{*}{$\begin{array}{l}\text { Main outcome of } \\
\text { protective ventilation }\end{array}$} \\
\hline & & & & $\begin{array}{l}\text { Tidal } \\
\text { volume }\end{array}$ & $\begin{array}{c}\text { PEEP } \\
\left(\mathrm{cmH}_{2} \mathrm{O}\right)\end{array}$ & $\begin{array}{l}\text { Tidal } \\
\text { volume }\end{array}$ & $\begin{array}{c}\text { PEEP } \\
\left(\mathrm{cmH}_{2} \mathrm{O}\right)\end{array}$ & \\
\hline $\begin{array}{l}\text { Chaney } \\
2000[14]\end{array}$ & 25 & $\mathrm{RCT}$ & CABG & $6 \mathrm{ml} / \mathrm{kg}$ & $\geq 5$ & $12 \mathrm{ml} / \mathrm{kg}$ & $\geq 5$ & $\begin{array}{l}\text { Better lung mechanics and less } \\
\text { shunt }\end{array}$ \\
\hline $\begin{array}{l}\text { Wrigge } \\
2004[18]\end{array}$ & 62 & RCT & $\begin{array}{l}\text { Major thoracic } \\
\text { or abdominal } \\
\text { surgery }\end{array}$ & $6 \mathrm{ml} / \mathrm{kg}$ IBW & 10 & $\begin{array}{c}12 \text { or } 15 \mathrm{ml} / \\
\mathrm{kg} \mathrm{IBW}\end{array}$ & 0 & $\begin{array}{l}\text { No difference in BAL or plasma } \\
\text { cytokines }\end{array}$ \\
\hline $\begin{array}{l}\text { Koner } \\
2004[15]\end{array}$ & 44 & RCT & CABG & $6 \mathrm{ml} / \mathrm{kg}$ & 5 & $\begin{array}{l}10 \mathrm{ml} / \mathrm{kg} \\
10 \mathrm{ml} / \mathrm{kg}\end{array}$ & $\begin{array}{l}5 \\
0\end{array}$ & $\begin{array}{l}\text { No difference in plasma } \\
\text { cytokines, better oxygenation in } \\
\text { PEEP groups }\end{array}$ \\
\hline $\begin{array}{l}\text { Wrigge } \\
2005[16]\end{array}$ & 44 & RCT & CABG & $6 \mathrm{ml} / \mathrm{kg} \mathrm{IBW}$ & $9^{a}$ & $12 \mathrm{ml} / \mathrm{kg}$ IBW & $7^{\mathrm{a}}$ & $\begin{array}{l}\text { No difference in BAL and plasma } \\
\text { cytokines }\end{array}$ \\
\hline $\begin{array}{l}\text { Zupancich } \\
2005 \text { [17] }\end{array}$ & 40 & RCT & CABG & $8 \mathrm{ml} / \mathrm{kg}$ & 10 & $10 \mathrm{ml} / \mathrm{kg}$ & $2-3$ & $\begin{array}{l}\text { Decrease in BAL and plasma } \\
\text { cytokines }\end{array}$ \\
\hline $\begin{array}{l}\text { Cai } \\
2006[27]\end{array}$ & 16 & RCT & Neurosurgery & $6 \mathrm{ml} / \mathrm{kg}$ & 0 & $10 \mathrm{ml} / \mathrm{kg}$ & 0 & $\begin{array}{l}\text { No difference in amount of } \\
\text { atelectasis or gas exchange }\end{array}$ \\
\hline $\begin{array}{l}\text { Determann } \\
2008[26]\end{array}$ & 40 & RCT & $\begin{array}{l}\text { Abdominal } \\
\text { surgery }\end{array}$ & $6 \mathrm{ml} / \mathrm{kg} \mathrm{IBW}$ & 10 & $12 \mathrm{ml} / \mathrm{kg}$ IBW & 0 & $\begin{array}{l}\text { No difference in BAL and plasma } \\
\text { of Clara cell protein, advanced } \\
\text { glycation end products and } \\
\text { surfactant proteins }\end{array}$ \\
\hline $\begin{array}{l}\text { Wolthuis } \\
2008[19]\end{array}$ & 40 & RCT & $\begin{array}{l}\text { Abdominal } \\
\text { surgery }\end{array}$ & $6 \mathrm{ml} / \mathrm{kg} \mathrm{IBW}$ & 10 & $12 \mathrm{ml} / \mathrm{kg}$ IBW & 0 & $\begin{array}{l}\text { Attenuated the increase in BAL } \\
\text { myeloperoxidase }\end{array}$ \\
\hline $\begin{array}{l}\text { Weingarten } \\
2010[20]\end{array}$ & 40 & RCT & $\begin{array}{l}\text { Abdominal } \\
\text { surgery } \\
\text { Age }>65 \text { years }\end{array}$ & 6 ml/kg PBW' & 12 & 10 ml/kg PBW & 0 & $\begin{array}{l}\text { Better intraoperative } \\
\text { oxygenation, no difference in } \\
\text { biomarkers }\end{array}$ \\
\hline $\begin{array}{l}\text { Fernandez- } \\
\text { Bustamante } \\
2011[22]\end{array}$ & 429 & Crosssectional & $\begin{array}{l}\text { Abdominal } \\
\text { surgery }\end{array}$ & $\begin{array}{c}<8 \mathrm{ml} / \mathrm{kg} \mathrm{PBW} \\
8-10 \mathrm{ml} / \mathrm{kg} \\
\mathrm{PBW}\end{array}$ & $\begin{array}{l}- \\
-\end{array}$ & $\begin{array}{l}>10 \mathrm{~mL} / \mathrm{kg} \\
\quad \mathrm{PBW}\end{array}$ & - & $\begin{array}{l}\text { Obesity, female gender or short } \\
\text { height risk factors for receiving } \\
\text { large } V_{T}\end{array}$ \\
\hline $\begin{array}{l}\text { Sundar } \\
2011[28]\end{array}$ & 149 & RCT & Cardiac surgery & $6 \mathrm{ml} / \mathrm{kg}$ PBW & $\geq 5^{\mathrm{a}}$ & 10 ml/kg PBW & $\geq 5^{\mathrm{a}}$ & $\begin{array}{l}\text { Less postoperative reintubation } \\
\text { and intubated patients at 6-8 } \\
\text { hours after surgery. }\end{array}$ \\
\hline $\begin{array}{l}\text { Lellouche } \\
2012[21]\end{array}$ & 3434 & Observational & Cardiac surgery & $\begin{array}{l}<10 \mathrm{ml} / \mathrm{kg} \\
\text { PBW }\end{array}$ & - & $\begin{array}{l}10-12 \mathrm{ml} / \mathrm{kg} \\
\mathrm{PBW} \\
>12 \mathrm{ml} / \mathrm{kg} \\
\mathrm{PBW}\end{array}$ & - & $\begin{array}{l}\mathrm{V}_{\mathrm{T}} \geq 10 \mathrm{ml} / \mathrm{kg} \text { independent } \\
\text { risk factor for organ failure and } \\
\text { prolonged ICU stay }\end{array}$ \\
\hline $\begin{array}{l}\text { Treschan } \\
2012[23]\end{array}$ & 101 & RCT & $\begin{array}{l}\text { Upper } \\
\text { abdominal } \\
\text { surgery }\end{array}$ & $6 \mathrm{ml} / \mathrm{kg}$ PBW & 5 & 12 ml/kg PBW & 5 & Did not improve lung function \\
\hline $\begin{array}{l}\text { Severgnini } \\
2013[24]\end{array}$ & 56 & RCT & $\begin{array}{l}\text { Open abdominal } \\
\text { surgery }\end{array}$ & $7 \mathrm{ml} / \mathrm{kg} \mathrm{IBW}^{\mathrm{b}}$ & 10 & $9 \mathrm{ml} / \mathrm{kg}$ IBW & 0 & $\begin{array}{l}\text { Better pulmonary function test } \\
\text { and mCPIS score, fewer chest } \\
\text { X-ray findings. }\end{array}$ \\
\hline $\begin{array}{l}\text { Futier } \\
2013[25]\end{array}$ & 400 & RCT & $\begin{array}{l}\text { Major abdominal } \\
\text { surgery }\end{array}$ & $\begin{array}{l}6-8 \mathrm{ml} / \mathrm{kg} \\
\mathrm{PBW}^{\mathrm{b}}\end{array}$ & $6-8$ & $\begin{array}{l}10-12 \mathrm{ml} / \mathrm{kg} \\
\text { PBW }\end{array}$ & 0 & $\begin{array}{l}\text { Less postoperative pulmonary } \\
\text { and extra pulmonary } \\
\text { complications. }\end{array}$ \\
\hline
\end{tabular}

No: number of patients; CABG: coronary artery bypass surgery; BAL: bronchoalveolar lavage; IBW: ideal body weight; PBW: predicted body weight; RCT: randomized control trial; ICU: intensive care unit; MV: mechanical ventilation; $\mathrm{V}_{\mathrm{T}}$ : tidal volume; mCPIS: modified Clinical Pulmonary Infection Score.

a Level of PEEP set according to the sliding scale based on $\mathrm{PaO}_{2} / \mathrm{FiO}_{2}$ ladder.

${ }^{\mathrm{b}}$ With recruitment maneuver.

ventilation with $\mathrm{V}_{\mathrm{T}}$ of $10 \mathrm{ml} / \mathrm{kg}$ [27] and application of PEEP may additionally counteract this effect [24]. Several studies have shown that protective ventilation can improve lung mechanics, gas exchange and decrease the incidence of postoperative pulmonary complications [24], [25], [28] (Table 1). 
To better investigate the impact of protective ventilation itself involving low $\mathrm{V}_{\mathrm{T}}$ or PEEP and recruitment maneuvers, a large RCT including 900 patients and investigating the effect on postoperative pulmonary complications of an open lung strategy with high PEEP and recruitment maneuvers in short term mechanical ventilation has recently been completed (PROVHILO) [29]. Finally, the impact of current mechanical ventilatory practice during general anesthesia on postoperative pulmonary complications will be revealed by another large prospective observational study (LAS VEGAS) [30].

\section{In the intensive care unit}

In a study comparing mechanical ventilation with $\mathrm{V}_{\mathrm{T}}$ of $6 \mathrm{ml} / \mathrm{kg}$ and $12 \mathrm{ml} / \mathrm{kg}$ but with the same level of PEEP $\left(5 \mathrm{~cm} \mathrm{H}_{2} \mathrm{O}\right)$ in a surgical ICU, the low $\mathrm{V}_{\mathrm{T}}$ group had a lower, but not significantly, incidence of pulmonary infections, duration of intubation, and duration of ICU stay [31]. Pinheiro de Oliveira et al. demonstrated in trauma and general ICU patients that protective ventilation $\left(\mathrm{V}_{\mathrm{T}} 5-7 \mathrm{ml} / \mathrm{kg}\right.$ PBW and PEEP $\left.5 \mathrm{~cm} \mathrm{H}_{2} \mathrm{O}\right)$ attenuated pulmonary IL- 8 and TNF- $\alpha$ compared with high $\mathrm{V}_{\mathrm{T}}$ ventilation (10-12 $\mathrm{ml} / \mathrm{kg}$ PBW and PEEP $5 \mathrm{~cm} \mathrm{H}_{2} \mathrm{O}$ ) after 12 hours of mechanical ventilation. Nevertheless, there were no differences in number of days on mechanical ventilation, length of ICU stay or mortality between the 2 groups [32]. Determann et al. also reported that conventional ventilation with $V_{T}$ $10 \mathrm{ml} / \mathrm{kg}$ was associated with a significantly lower clearance rate of plasma IL-6 compared to protective ventilation with a $V_{T} 6 \mathrm{ml} / \mathrm{kg}$ PBW [33]. This trial was stopped early because more patients in the conventional ventilation group developed acute lung injury (ALI, 10 patients [13.5\%] vs. 2 patients [2.6\%], p = 0.01) [33].

Not only a high $\mathrm{V}_{\mathrm{T}}$ but also the time of exposure can lead to the release of pro-inflammatory mediators and an increase in the wet-to-dry ratio in the lung [34]. In a large retrospective cohort study in ICU patients who received mechanical ventilation for $>48$ hours, $24 \%$ of 332 patients developed acute lung injury (ALI) within 5 days. A $V_{\mathrm{T}}>6 \mathrm{ml} / \mathrm{kg}$ PBW (OR 1.3 for each $\mathrm{ml}$ above $6 \mathrm{ml} / \mathrm{kg}$ PBW, $\mathrm{p}<0.001$ ), history of blood transfusion, acidemia, and history of restrictive lung disease were independent risk factors for development of ALI [35]. The incidence of ARDS decreased from $28 \%$ to $10 \%$ when applying a quality improvement intervention, namely setting $\mathrm{V}_{\mathrm{T}}$ at $6-8 \mathrm{ml} / \mathrm{kg}$ PBW in patients at risk of ARDS plus using a restrictive protocol for red blood cell (RBC) transfusion [36]. Lower $\mathrm{V}_{\mathrm{T}}$ ventilation was also not associated with differences in sedative drug dosage [37].

\section{Recent meta-analyses}

Serpa Neto et al. [38] performed a meta-analysis of 20 trials that compared higher and lower $\mathrm{V}_{\mathrm{T}}$ ventilation in critically ill patients and surgical patients who did not meet the consensus criteria for ARDS. Patients who received lower $\mathrm{V}_{\mathrm{T}}$ ventilation showed a decrease in the development of ALI (risk ratio [RR] 0.33, $95 \%$ CI 0.230.47 , number needed to treat [NNT] 11), pulmonary infection (RR 0.45, 95 \% CI 0.22-0.92, NNT 26), atelectasis (RR 0.62, $95 \%$ CI $0.41-0.95$ ) and mortality (RR 0.64, $95 \%$ CI 0.46-0.86, NNT 23) [38]. However, there are some limitations that need to be addressed in the design of this meta-analysis. Some of the included studies were small, five studies were observational and studies included various types of clinical settings, such as sepsis in the ICU and one-lung ventilation in the operating room [36], [39]. Therefore, the results of this study cannot be considered as definitive.

To better specify the effect of protective ventilation in cardiac and abdominal surgical patients, excluding ICU patients, Hemmes et al. [40] performed a meta-analysis focusing on the effects of protective ventilation on the incidence of postoperative pulmonary complications and included eight articles. These authors demonstrated that applying protective ventilation decreased the incidence of lung injury (RR $0.40,95 \%$ CI $0.22-0.70$, NNT 37), pulmonary infection (RR 0.64, $95 \%$ CI $0.43-0.97$, NNT 27 ) and atelectasis (RR $0.67,95 \%$ CI 0.47-0.96, NNT 31). When comparing lower PEEP and higher PEEP, higher PEEP also attenuated postoperative lung injury (RR 0.29, $95 \%$ CI 0.14-0.60, NNT 29), pulmonary infection (RR $0.62,95 \%$ CI $0.40-0.96$, NNT 33) and atelectasis (RR $0.61,95 \%$ CI 0.41-0.91, NNT 29).

The most recent systematic review was performed by Fuller et al. [41]. These authors hypothesized that low $\mathrm{V}_{\mathrm{T}}$ is associated with a decreased incidence in the progression to ARDS in patients without ARDS at the time of initiation of mechanical ventilation. Thirteen studies were included and only one was a RCT. The majority of these studies showed that low $\mathrm{V}_{\mathrm{T}}$ could decrease the progression of ARDS. However, a formal meta-analysis was not conducted because of the marked heterogeneity and variability of baseline ARDS among included patients [41].

\section{Meta-analysis including the most recent trials}

From the results of two additional recently published RCTs, which included overall more than 400 patients [24], [25], we hypothesized that the use of a protective ventilator strategy, defined as physiologically low $\mathrm{V}_{\mathrm{T}}$ with moderately high PEEP with or without recruitment maneuvers, could lead to a substantial decrease in pulmonary complications in non-injured lungs and may affect mortality. Therefore, we conducted a new metaanalysis restricted to RCTs in patients undergoing surgery and critically ill patients, and excluding one-lung ventilation. Studies were identified by two authors 
Table 2. Characteristics of the studies included in the meta-analysis

\begin{tabular}{|c|c|c|c|c|c|c|c|c|}
\hline \multirow{2}{*}{$\begin{array}{l}\text { First author, } \\
\text { Year [Ref] }\end{array}$} & \multirow{2}{*}{$\begin{array}{c}\text { Number of } \\
\text { patients }\end{array}$} & \multicolumn{2}{|c|}{ Protective ventilation } & \multicolumn{2}{|c|}{ Standard ventilation } & \multirow[b]{2}{*}{ Setting } & \multirow[b]{2}{*}{ Design } & \multirow[b]{2}{*}{ Primary outcome } \\
\hline & & $\mathrm{V}_{\mathrm{T}}(\mathrm{ml} / \mathrm{kg})$ & $\mathrm{N}$ & $\mathrm{V}_{\mathrm{T}}(\mathrm{ml} / \mathrm{kg})$ & $\mathrm{N}$ & & & \\
\hline Lee 1990 [31] & 103 & 6 & 47 & 12 & 56 & $\mathrm{ICU}$ & RCT & Duration of MV \\
\hline Chaney 2000 [14] & 25 & 6 & 12 & 12 & 16 & Surg & RCT & Lung mechanics \\
\hline Wrigge 2004 [18] & 62 & 6 & 30 & 12 & 32 & Surg & RCT & Cytokines in BAL \\
\hline Koner 2004 [15] & 44 & 6 & 15 & 10 & 29 & Surg & RCT & Cytokines in blood \\
\hline Wrigge 2005 [16] & 44 & 6 & 22 & 12 & 22 & Surg & RCT & Cytokines in BAL \\
\hline Zupancich 2005 [17] & 40 & 8 & 20 & 10 & 20 & Surg & RCT & Cytokines in BAL \\
\hline Michelet 2006 [43] & 52 & 5 & 26 & 9 & 26 & Surg & RCT & Cytokines in blood \\
\hline Cai 2007 [27] & 16 & 6 & 8 & 10 & 8 & Surg & RCT & Atelectasis \\
\hline Wolthius 2008 [19] & 40 & 6 & 21 & 12 & 19 & Surg & RCT & Pulmonary Inflammation \\
\hline Determan 2008 [26] & 40 & 6 & 21 & 12 & 19 & Surg & RCT & Cytokines in BAL \\
\hline Weingarten 2010 [20] & 40 & 6 & 20 & 10 & 20 & Surg & $\mathrm{RCT}$ & Oxygenation \\
\hline Determann 2010 [33] & 150 & 6 & 76 & 10 & 74 & ICU & RCT & Cytokines in BAL \\
\hline Pinheiro de Oliveira 2010 [32] & 20 & 6 & 10 & 12 & 10 & $\mathrm{ICU}$ & RCT & Cytokines in BAL \\
\hline Sundar 2011 [28] & 149 & 6 & 75 & 10 & 74 & Surg & RCT & Duration of MV \\
\hline Treschan 2012 [23] & 101 & 6 & 50 & 12 & 51 & Surg & RCT & Spirometry \\
\hline Severgnini 2013 [24] & 55 & 7 & 27 & 9 & 28 & Surg & RCT & Change in $\mathrm{mCPIS}$ \\
\hline Futier 2013 [25] & 400 & $6-8$ & 200 & $10-12$ & 200 & Surg & $\mathrm{RCT}$ & $\begin{array}{l}\text { Pulmonary and } \\
\text { extrapulmonary } \\
\text { complications }\end{array}$ \\
\hline
\end{tabular}

BAL: bronchoalveolar lavage; ICU: intensive care unit; MV: mechanical ventilation; Surg: surgical; $\mathrm{V}_{\mathrm{T}}$ : tidal volume; $\mathrm{mCPIS}$ : modified Clinical Pulmonary Infection Score.

through a computerized blind search of Pubmed using a sensitive search strategy. Articles were selected for inclusion in the systematic review if they evaluated two types of ventilation in patients without ARDS or ALI at the onset of mechanical ventilation in the operating room or ICU. Protective ventilation was defined as low $\mathrm{V}_{\mathrm{T}}$ with or without high PEEP, and standard ventilation was defined as high $\mathrm{V}_{\mathrm{T}}$ with or without low PEEP. Articles not reporting outcomes of interest were excluded. Data were independently extracted from each report by two investigators using a data recording form developed for this purpose. We extracted data regarding study design, patient characteristics, type of ventilation, and mean change in arterial blood gases, lung injury development, and ICU and hospital length of stay, overall survival, and incidence of atelectasis. The longest follow-up period in each trial up to hospital discharge was used in the analysis. After extraction, the data were reviewed and compared by a third investigator. Whenever needed, we obtained additional information about a specific study by directly questioning the principal investigator. We assessed allocation concealment, the baseline similarity of groups (with regard to age, severity of illness, and severity of lung injury), and early treatment cessation.

The primary endpoint was the development of lung injury in each study group. Secondary endpoints included incidence of lung infection, atelectasis, length of ICU stay, length of hospital stay and mortality. Continuous outcome data were evaluated with a meta-analysis of risk ratio performed with a fixed-effects model according to Mantel and Haenszel. When heterogeneity was > $25 \%$, we performed a meta-analysis with mixed random effect using the DerSimonian and Laird method. Results were graphically represented using Forest plot graphs. The homogeneity assumption was measured by the $I^{2}$, which describes the percentage of total variation across studies that is due to heterogeneity rather than to chance; a value of $0 \%$ indicates no observed heterogeneity, and larger values show increasing heterogeneity. Parametric variables are presented as mean and standard deviation, and nonparametric variables as median and interquartile range (IQR). All analyses were conducted with OpenMetaAnalyst (version 6), Prism 6 (GraphPad software) and SPSS version 20 (IBM SPSS). For all analyses, 2 -sided $\mathrm{p}$ values less than 0.05 were considered significant. To evaluate potential publication bias, a weighted linear regression was used, with the natural log of the OR as the dependent variable and the inverse of the total sample size as the independent variable. This is a modified Macaskill's test, which gives more balanced type I error rates in the tail probability areas in comparison to other publication bias tests [42].

Seventeen articles were included in the meta-analysis [14]-[20], [23]-[28], [31]-[33], [43]. Three studies were 
Table 3. Demographic, ventilation and laboratory characteristics of the patients included in the different studies

\begin{tabular}{lccc}
\hline & Protective ventilation $(\boldsymbol{n = 6 8 2})$ & Standard ventilation $(\boldsymbol{n}=\mathbf{6 8 0})$ & $\mathbf{p}$ \\
\hline Age, years & $61(8.4)$ & $61(7.7)$ & 0.96 \\
Weight, $\mathrm{kg}$ & $77.5(10.1)$ & $77.2(9.5)$ & 0.82 \\
Tidal volume, $\mathrm{ml} / \mathrm{kg}$ & $6.1(0.63)$ & $10.7(1.2)$ & 0.00 \\
$\mathrm{PEEP}, \mathrm{cm} \mathrm{H} \mathrm{O}_{2} \mathrm{O}$ & $7.6(2.4)$ & $2.5(2.6)$ & 0.00 \\
Plateau pressure, $\mathrm{cm} \mathrm{H}_{2} \mathrm{O}$ & $17.2(2.2)$ & $19.9(3.9)$ & 0.03 \\
Respiratory rate, breaths/min & $16.7(3.2)$ & $10.1(3.5)$ & 0.00 \\
$\mathrm{PaO}_{2} / \mathrm{FiO}_{2}$ & $331.6(62.3)$ & $332.5(64.3)$ & 0.94 \\
$\mathrm{PaCO}_{2^{\prime}} \mathrm{mmHg}$ & $42.6(5.5)$ & $38.4(4.8)$ & 0.01 \\
$\mathrm{pH}$ & $7.37(0.3)$ & $7.40(0)$ & 0.01 \\
\hline
\end{tabular}

Results are shown as mean ( $\pm \mathrm{SD})$. $\mathrm{FiO}_{2}$ : fraction of inspired oxygen; PEEP: positive end-expiratory pressure.

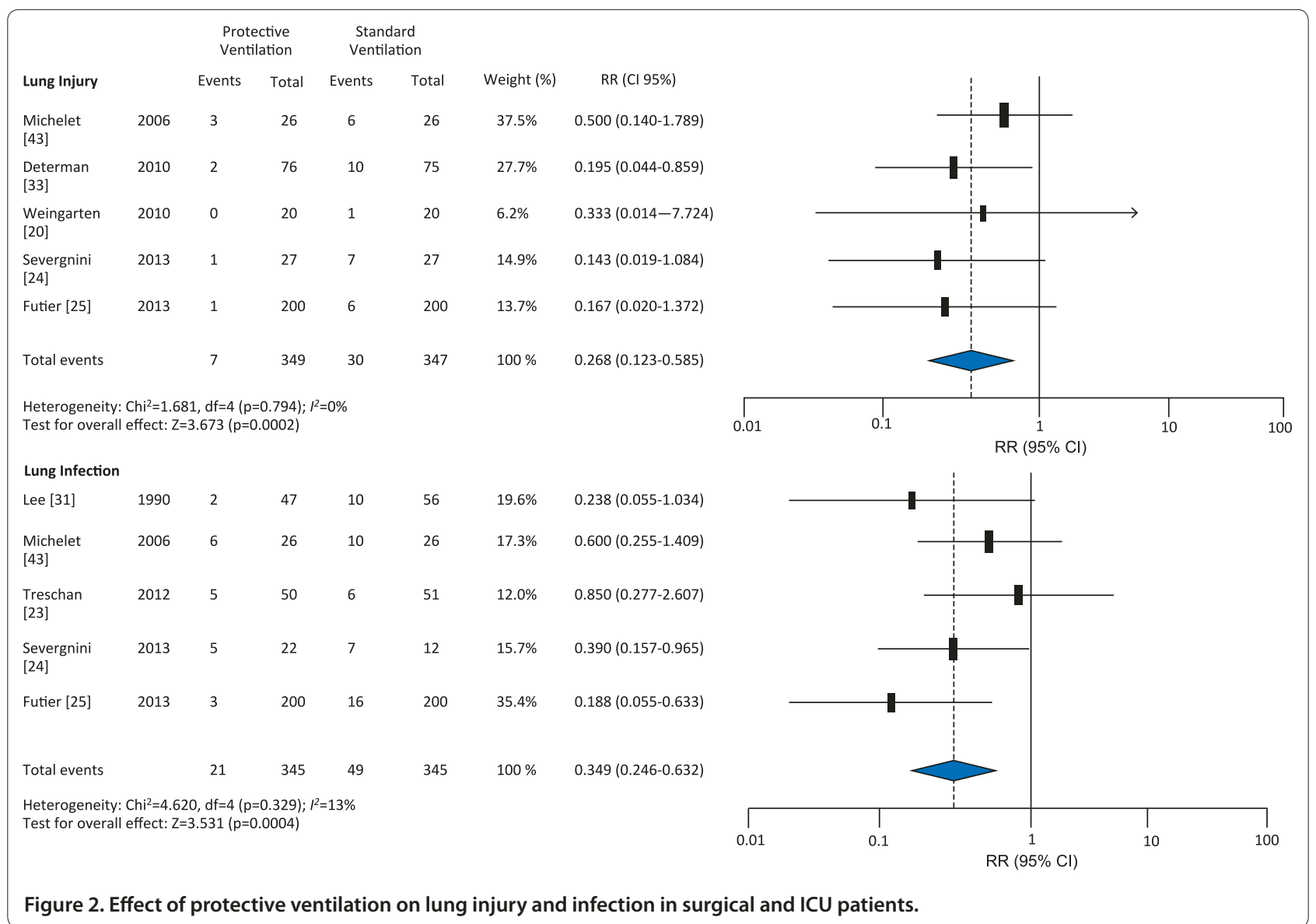

conducted in critically ill patients and the others in surgical patients. Six of the studies were in cardiac surgery, 6 in major abdominal surgery, 1 in neurosurgery, and 1 in thoracic surgery. A total of 1362 patients, comprising 682 patients with protective ventilation and 680 patients with conventional ventilation, were analyzed. Characteristics of the included RCTs are shown in Table 2. Nine studies evaluated inflammatory mediators as their primary outcome. The development of pulmonary complications was the primary outcome in three studies. The average $\mathrm{V}_{\mathrm{T}}$ values in the protective ventilation and conventional ventilation groups were $6.1 \mathrm{ml} / \mathrm{kg} \mathrm{IBW}$ and $10.7 \mathrm{ml} / \mathrm{kg}$, respectively. The average plateau pressures were $<20 \mathrm{~cm} \mathrm{H}_{2} \mathrm{O}$ in both groups, significantly lower in the protective ventilation group than in the conventional ventilation group. The protective 


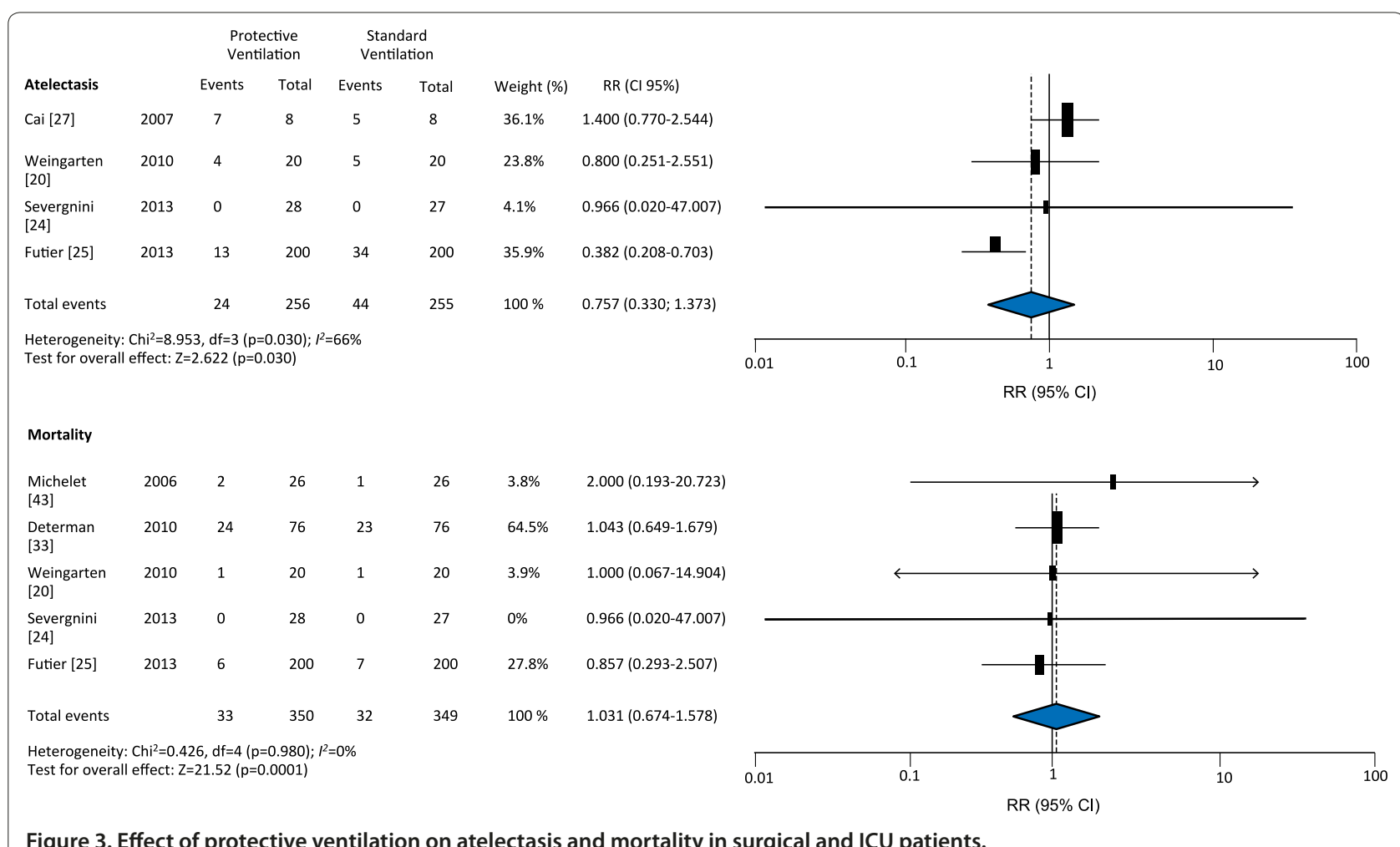

Figure 3. Effect of protective ventilation on atelectasis and mortality in surgical and ICU patients.

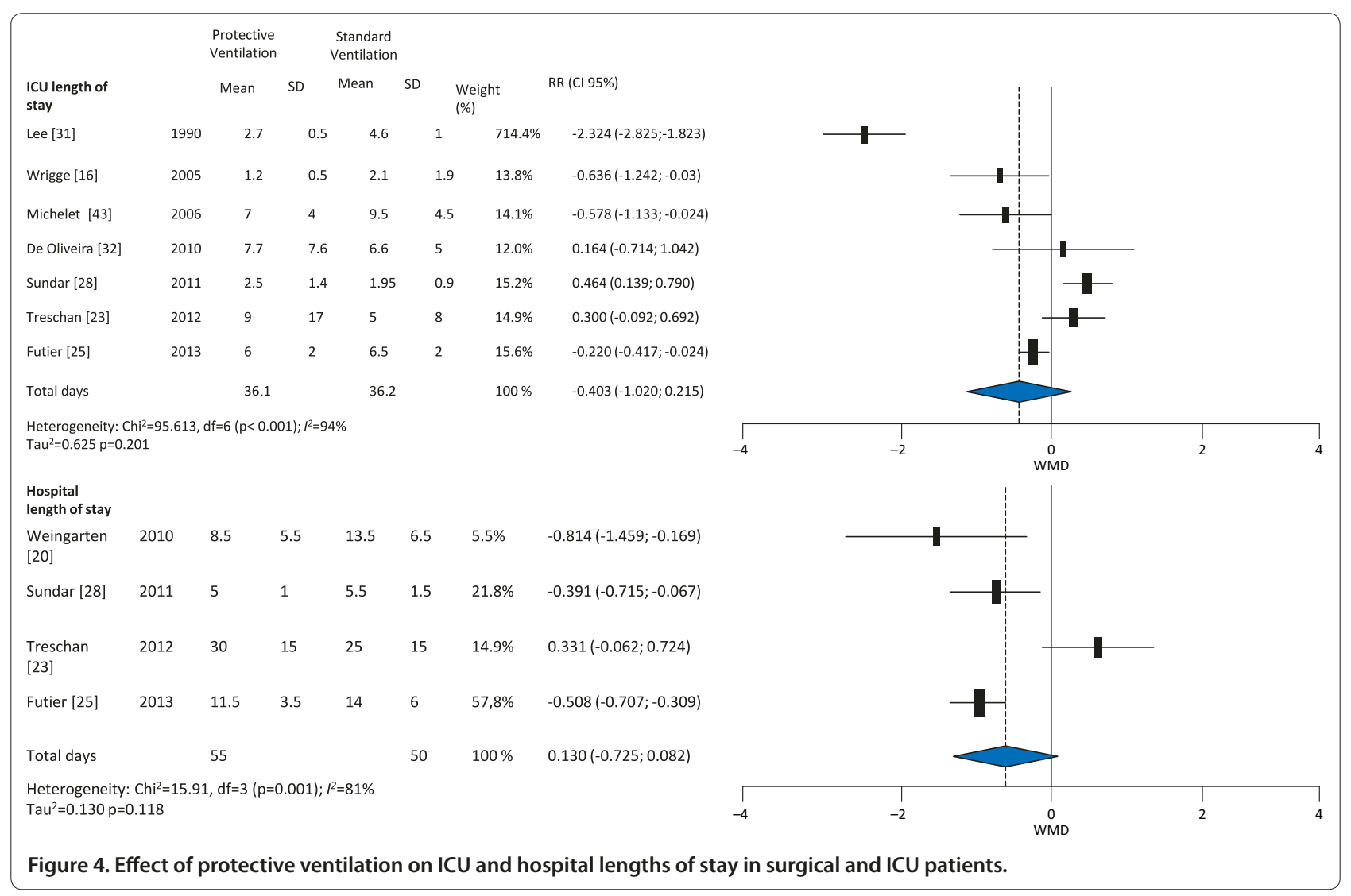


Table 4. Characteristics and outcomes of three recent meta-analyses

\begin{tabular}{|c|c|c|c|c|c|c|}
\hline Author, year [ref] & \multicolumn{2}{|c|}{ Serpa Neto et al. 2012 [38] } & \multicolumn{2}{|c|}{ Hemmes et al. 2013 [40] } & \multicolumn{2}{|c|}{ Our meta-analysis } \\
\hline Number of studies & \multicolumn{2}{|l|}{20 articles } & \multicolumn{2}{|l|}{8 articles } & \multicolumn{2}{|l|}{17 articles } \\
\hline Number of RCTs & \multicolumn{2}{|l|}{15 articles } & \multicolumn{2}{|l|}{6 articles } & \multicolumn{2}{|l|}{17 articles } \\
\hline Populations & \multicolumn{2}{|c|}{ ICU and surgical patients } & \multicolumn{2}{|c|}{ Only surgical patients } & \multicolumn{2}{|c|}{ ICU and surgical patients } \\
\hline Search strategy until (year) & \multicolumn{2}{|l|}{2012} & \multicolumn{2}{|l|}{2012} & \multicolumn{2}{|l|}{2013} \\
\hline Statistical analysis & \multicolumn{2}{|c|}{ Fixed effect + Mantel and Haenszel } & \multicolumn{2}{|c|}{ Fixed effect + Mantel and Haenszel } & \multicolumn{2}{|c|}{$\begin{array}{l}\text { Fixed effect + Mantel and Haenszel, } \\
\text { when } R^{2}>25 \% \text { random effect plus } \\
\text { DerSimonian and Laird }\end{array}$} \\
\hline \multirow[t]{2}{*}{ Number of patients } & \multicolumn{2}{|l|}{2833} & \multicolumn{2}{|l|}{1669} & \multicolumn{2}{|l|}{1362} \\
\hline & PV group & CV group & PV group & CV group & PV group & CV group \\
\hline$V_{T}(\mathrm{ml} / \mathrm{kg})$ & 6.5 & 10.6 & 6.1 & 10.4 & 6.1 & 10.7 \\
\hline $\operatorname{PEEP}\left(\mathrm{cm} \mathrm{H}_{2} \mathrm{O}\right)$ & 6.4 & 3.4 & 6.6 & 2.7 & 7.6 & 2.5 \\
\hline Plateau pressure $\left(\mathrm{cmH}_{2} \mathrm{O}\right)$ & 16.6 & 21.4 & 16.6 & 20.5 & 17.2 & 19.9 \\
\hline \multicolumn{7}{|l|}{ Main outcome } \\
\hline ALI & \multicolumn{2}{|c|}{ RR $0.33 ; 95 \% \mathrm{Cl} 0.23-0.47$} & \multicolumn{2}{|c|}{ RR 0.40; $95 \%$ Cl 0.22-0.70 } & \multicolumn{2}{|c|}{ RR $0.27 ; 95 \%$ Cl 0.12-0.59 } \\
\hline Pulmonary infection & \multicolumn{2}{|c|}{ RR $0.52 ; 95 \% \mathrm{Cl} 0.33-0.82$} & \multicolumn{2}{|c|}{ RR 0.64; $95 \%$ Cl 0.43-0.97 } & \multicolumn{2}{|c|}{ RR $0.35 ; 95 \%$ Cl $0.25-0.63$} \\
\hline Atelectasis & \multicolumn{2}{|c|}{ RR $0.62 ; 95 \% \mathrm{Cl} 0.41-0.95$} & \multicolumn{2}{|c|}{ RR $0.67 ; 95 \%$ Cl $0.47-0.96$} & \multicolumn{2}{|c|}{ RR 0.76; $95 \%$ Cl 0.33-1.37 } \\
\hline Mortality & \multicolumn{2}{|c|}{ RR $0.64 ; 95 \% \mathrm{Cl} 0.46-0.86$} & \multicolumn{2}{|l|}{ No data } & \multicolumn{2}{|c|}{ RR 1.03; $95 \%$ Cl 0.67-1.58 } \\
\hline ICU length of stay & \multicolumn{2}{|l|}{ No data } & No data & & WMD -0.4 & $-1.02 ; 0.22$ \\
\hline Hospital length of stay & No data & & No data & & WMD 0.13 & $0.73 ; 0.08$ \\
\hline Homogeneity test & $\begin{array}{l}\text { Found het } \\
\text { infection o }\end{array}$ & in pulmonary & $\begin{array}{l}\text { Found he } \\
\text { outcome }\end{array}$ & $y$ in atelectasis & $\begin{array}{l}\text { Found het } \\
\text { ICU length } \\
\text { length of }\end{array}$ & $\begin{array}{l}\text { y in atelectasis, } \\
\text { id hospital } \\
\text { me }\end{array}$ \\
\hline
\end{tabular}

$\mathrm{RCT}$ : randomized control trial; $\mathrm{V}_{\mathrm{i}}$ : tidal volume; PEEP: positive end-expiratory pressure; PV: protective ventilation; $\mathrm{CV}$ : conventional ventilation; ICU: intensive care unit; RR: risk ratio; $95 \%$ Cl: $95 \%$ confidence interval. WMD: weighted mean difference.

ventilation groups had higher levels of $\mathrm{PaCO}_{2}$ and more acidemia, although within the normal ranges (Table 3 ).

The protective ventilation group had a lower incidence of ALI (RR 0.27, $95 \%$ CI 0.12-0.59) and lung infection (RR 0.35, 95 \% CI 0.25-0.63); however, application of protective ventilation did not affect atelectasis (RR 0.76, 95 \% CI 0.33-1.37) or mortality (RR 1.03; 95 \% CI 0.671.58) compared with conventional ventilation (Figures 2 and 3). There were no differences in length of ICU stay (weighted mean difference [WMD] -0.40, $95 \%$ CI -1.02; 0.22 ) or length of hospital stay (WMD 0.13, $95 \% \mathrm{CI}$ -0.73 ; 0.08 ) (Figure 4 ) between the protective ventilation and conventional ventilation groups. The $I^{2}$ test revealed no heterogeneity in the analysis of lung injury and mortality, but there was heterogeneity in the analysis of atelectasis and length of stay.

Our meta-analysis including the most recent trials suggests that among surgical and critically ill patients without lung injury, protective mechanical ventilation with use of lower $\mathrm{V}_{\mathrm{T}}$, with or without PEEP, is associated with better clinical pulmonary outcomes in term of ARDS incidence and pulmonary infection but does not decrease atelectasis, mortality or length of stay. The plateau pressure in the conventional group was less than
$20 \mathrm{~cm} \mathrm{H}_{2} \mathrm{O}$, indicating that ARDS can occur even below the previously-believed safe plateau pressure level. The meta-analysis by Serpa Neto et al. [38] demonstrated that mortality was significantly lower with protective ventilation than in our study. This finding can be explained by the fact that we included only RCTs in our meta-analysis and the two most recent RCTs were not analyzed in the previous study. We summarize the characteristics of each recent meta-analysis Table 4.

\section{In specific populations}

\section{Donors}

A prospective multicenter study in brain death patients reported that $45 \%$ of potential lung donors have a $\mathrm{PaO}_{2} /$ $\mathrm{FiO}_{2}<300$, making them ineligible for lung donation. The authors suggest that mechanical ventilation management should be changed to protective ventilation settings to improve the supply of donor lungs [44]. Mascia et al. compared a protective mechanical ventilation strategy, including $\mathrm{V}_{\mathrm{T}}$ of 6-8 ml/kg PBW, PEEP of 8-10 $\mathrm{cm} \mathrm{H}_{2} \mathrm{O}$, apnea tests performed by using continuous positive airway pressure (CPAP), closed circuit for airway suction and recruitment maneuver performed after each ventilator disconnection, with conventional ventilation, 
namely $\mathrm{V}_{\mathrm{T}}$ of $10-12 \mathrm{ml} / \mathrm{kg}$ PBW, PEEP $3-5 \mathrm{~cm} \mathrm{H}_{2} \mathrm{O}$, apnea test performed by disconnecting the ventilator and open circuit airway suctioning, in potential donors. The authors clearly demonstrated that the number of lungs that met lung donor eligibility criteria after the 6-hour observation period and the number of lungs eligible to be harvested were nearly two times higher with protective ventilation compared to traditional mechanical ventilation [45]. The authors concluded that these strategies can prevent the lungs from ARDS caused by brain injury and can recruit atelectasis.

\section{One-lung ventilation}

Michelet et al. demonstrated that during one-lung ventilation, protective ventilation resulted in higher $\mathrm{PaO}_{2} / \mathrm{FiO}_{2}$ ratios and shortened duration of postoperative mechanical ventilation in patients undergoing esophagectomy compared to conventional ventilation [43]. In patients undergoing esophagectomy, protective ventilation during one-lung ventilation causes lower serum levels of IL-1, IL-6, and IL-8 [43], [46]. In lobectomy patients, during one lung ventilation, Yang et al. reported that applying $\mathrm{V}_{\mathrm{T}}$ of $6 \mathrm{ml} / \mathrm{kg}$ PBW, PEEP $5 \mathrm{~cm} \mathrm{H}_{2} \mathrm{O}$ and $\mathrm{FiO}_{2} 0.5$ decreased the incidence of pulmonary complications and improved oxygenation indices compared to conventional ventilation [47].

\section{Obesity}

Obesity can aggravate atelectasis formation and is one of the risk factors for receiving high $V_{T}$ values [21]. In morbid obesity, the forced vital capacity, maximal voluntary ventilation and expiratory reserve volume are markedly reduced. During anesthesia, an increase in body mass index correlates well with decreasing lung volume, lung compliance and oxygenation [48] but increasing lung resistance. The decrease of FRC is linked with atelectasis formation consequent to hypoxemia [49]. Ventilator management during anesthesia in obesity should be set as follows: (a) low $\mathrm{V}_{\mathrm{T}}$; (b) open lung approach with PEEP and recruitment maneuvers; (c) low $\mathrm{FiO}_{2}$, less than 0.8 [49]. Because of the effects of chest wall and intra-abdominal pressure, we recommend careful monitoring of airway plateau pressure, intrinsic PEEP and transpulmonary pressure. Further studies are warranted to define protective ventilation settings in this group and particularly during the perioperative period.

\section{Conclusions}

Although, mechanical ventilation is a supportive tool in patients with respiratory failure and during the perioperative period, it has proved to be a double-edged sword. Mechanisms of VILI are now better understood. Implementation of protective ventilator strategies, consisting of $\mathrm{V}_{\mathrm{T}}$ of $6 \mathrm{ml} / \mathrm{kg}$, PEEP of 6-12 $\mathrm{cm} \mathrm{H}_{2} \mathrm{O}$ and recruitment maneuvers can decrease the development of ARDS, pulmonary infection and atelectasis but not mortality in previously non-injured lungs in the perioperative period and the ICU.

\section{List of abbreviations used}

ABW: actual body weight; ALI: acute lung injury; ARDS: acute respiratory distress syndrome; BAL: bronchoalveolar lavage; CABG: coronary artery bypass surgery; Cl: confidence interval; CPB: cardiopulmonary bypass; CV: conventional ventilation; ECM: extracellular matrix; EELV: end-expiratory lung volume; FRC: functional residual capacity; GAGs: glycosaminoglycans; IBW: ideal body weight; ICU: intensive care unit; IL: interleukin; mCPIS: modified Clinical Pulmonary Infection Score; MMP: matrix metalloproteinase; MV: mechanical ventilation; NF-KB: nuclear factor-kappa B; NNT: number needed to treat; OR: odds ratio; PBW: predicted body weight; PEEP: positive-end expiratory pressure; PV: protective ventilation; RBC: red blood cell; RCTs: randomized controlled trials; RR: risk ratio; RV: right ventricular; TNF: tumor necrosis factor; VILI@ ventilator-induced lung injury; $V_{\text {T: }}$ tidal volume; WMD: weighted mean difference; ZEEP: zero end-expiratory pressure.

\section{Competing interests}

The authors declare that they have no competing interests.

\section{Declarations}

Publication of this article was funded by Dipartimento di Scienze Chirurgiche e Diagnostiche integrate (DISC), Section Anesthesiology, Università degli Studi di Genova (Professor Paolo Pelosi).

\section{Author details}

'Division of Pulmonary and Critical Care Unit, Department of Medicine, Ramathibodi Hospital, Mahidol University, Bangkok, Thailand. '² Department of Neuroscience and Reproductive and Odontostomatological Sciences, University of Naples "Federico II", Naples, Italy. ${ }^{3}$ AOU IRCCS San Martino-IST, Department of Surgical Sciences and Integrated Diagnostics, University of Genoa, Genoa, Italy.

Published: 18 March 2014

\section{References}

1. De Prost N, Dreyfuss D: How to prevent ventilator-induced lung injury? Minerva Anestesio/ 2012, 78:1054-1066

2. Pelosi P, Negrini D: Extracellular matrix and mechanical ventilation in healthy lungs: back to baro/volotrauma? Curr Opin Crit Care 2008, 14:16-21

3. Lionetti V, Recchia FA, Ranieri VM: Overview of ventilator-induced lung injury mechanisms. Curr Opin Crit Care 2005, 11:82-86.

4. Wilson MR, Choudhury S, Goddard ME, O'Dea KP, Nicholson AG, Takata M: High tidal volume upregulates intrapulmonary cytokines in an in vivo mouse model of ventilator-induced lung injury. J Appl Physiol 2003, 95:1385-1393.

5. Pelosi P, Rocco PR (2008) Effects of mechanical ventilation on the extracellular matrix. Intensive Care Med 34:631-639

6. Protti A, Cressoni M, Santini A, Langer T, Mietto C, Febres D, Chierchetti M, Coppola S, Conte G, Gatti S, Leopardi O, Masson S, Lombardi L, Lazzerini M, Rampoldi E, Cadringher P, Gattinoni L: Lung stress and strain during mechanical ventilation: any safe threshold? Am J Respir Crit Care Med 2011, 183:1354-1362.

7. Souza-Fernandes AB, Pelosi P, Rocco PR: Bench-to-bedside review: the role of glycosaminoglycans in respiratory disease. Crit Care 2006, 10:237.

8. Duggan M, Kavanagh BP: Pulmonary atelectasis: a pathogenic perioperative entity. Anesthesiology 2005, 102:838-854.

9. Tusman G, Bohm SH, Warner DO, Sprung J: Atelectasis and perioperative pulmonary complications in high-risk patients. Curr Opin Anaesthesiol 2012, 25:1-10.

10. Pearse RM, Moreno RP, Bauer P, Pelosi P, Metnitz P, Spies C, Vallet B, Vincent JL, Hoeft A, Rhodes A, European Surgical Outcomes Study (EuSOS) group for the Trials groups of the European Society of Intensive Care Medicine and the European Society of Anaethesiology: Mortality after surgery in Europe: a 7 day cohort study. Lancet 2012, 380:1059-1065.

11. Bendixen HH, Hedley-Whyte J, Laver MB: Impaired oxygenation in surgical patients during general anesthesia with controlled ventilation. A concept of atelectasis. N Engl J Med 1963, 269:991-996. 
12. Hager DN, Krishnan JA, Hayden DL, Brower RG, Network ACT: Tidal volume reduction in patients with acute lung injury when plateau pressures are not high. Am J Respir Crit Care Med 2005, 172:1241-1245.

13. Esteban A, Frutos-Vivar F, Muriel A, Ferguson ND, Peñyelas O, Abraira V, Raymondos K, Rios F, Nin N, Apeztequía C, Violi DA< Thille AW, Brochard L, González M, Villagomez AJ, Hurtado J, Davies AR, Du B, Maggiore SM, Pelosi P, Soto L, Tomicic C, D'Empaire G, Matamis D, Abroug F, Moreno RP, Soares MA, Arabi Y, Sandi F, Jibaja M, Amin P, Koh Y, Kuiper MA, Bülow HH, Zeggwagh AA, Anzueto A: Evolution of mortality over time in patients receiving mechanical ventilation. Am J Respir Crit Care Med 2013, 188:220-230.

14. Chaney MA, Nikolov MP, Blakeman BP, Bakhos M: Protective ventilation attenuates postoperative pulmonary dysfunction in patients undergoing cardiopulmonary bypass. J Cardiothorac Vasc Anesth 2000, 14:514-518.

15. Koner O, Celebi S, Balci H, Cetin G, Karaoglu K, Cakar N: Effects of protective and conventional mechanical ventilation on pulmonary function and systemic cytokine release after cardiopulmonary bypass. Intensive Care Med 2004, 30:620-626.

16. Wrigge H, Uhlig U, Baumgarten G, Menzenbach J, Zinerling J, Ernst M, Drömann D, Welz A, Uhliq S, Putensen C: Mechanical ventilation strategies and inflammatory responses to cardiac surgery: a prospective randomized clinical trial. Intensive Care Med 2005, 31:1379-1387.

17. Zupancich E, Paparella D, Turani F, Munch C, Rossi A, Massaccesi S, Ranieri VM: Mechanical ventilation affects inflammatory mediators in patients undergoing cardiopulmonary bypass for cardiac surgery: a randomized clinical trial. J Thorac Cardiovasc Surg 2005, 130:378-383.

18. Wrigge H, Uhlig U, Zinserling J, Behrends-Callsen E, Ottersbach G, Fischer M, Uhliq S, Putensen C: The effects of different ventilatory settings on pulmonary and systemic inflammatory responses during major surgery. Anesth Analg 2004, 98:775-781.

19. Wolthuis EK, Choi G, Dessing MC, Bresser P, Lutter R, Dzoljic M, van der PollT, Vroom MB, Hollmann M, Schultz MJ: Mechanical ventilation with lower tidal volumes and positive end-expiratory pressure prevents pulmonary inflammation in patients without preexisting lung injury. Anesthesiology 2008, 108:46-54.

20. Weingarten TN, Whalen FX, Warner DO, Gajic O, Schears GJ, Snyder MR, Schroeder DR, Sprung J:Comparison of two ventilatory strategies in elderly patients undergoing major abdominal surgery. Br J Anaesth 2010, 104:16-22.

21. Lellouche F, Dionne S, Simard S, Bussieres J, Dagenais F: High tidal volumes in mechanically ventilated patients increase organ dysfunction after cardiac surgery. Anesthesiology 2012, 116:1072-1082

22. Fernandez-Bustamante A, Wood CL, Tran ZV, Moine P: Intraoperative ventilation: incidence and risk factors for receiving large tidal volumes during general anesthesia. BMC Anesthesiol 2011, 11:22.

23. Treschan TA, Kaisers W, Schaefer MS, Bastin b, Schmalz U, Wania V, Eisenberger CF, Saleh A, Weiss M, Schmitz A, Kienbaum P, Sessler DI, Pannen B, Beiderlinden M: Ventilation with low tidal volumes during upper abdominal surgery does not improve postoperative lung function. $\mathrm{Br}$ 」 Anaesth 2012, 109:263-271.

24. Severgnini P, Selmo G, Lanza C, Chiesa A, Frigerio A, Bacuzzi A, Dionigi G, Novario R, Gregoretti C, de Abreu MG, Schultz MJ, Jaber S, Futier E, Chiaranda $M$, Pelosi P: Protective mechanical ventilation during general anesthesia for open abdominal surgery improves postoperative pulmonary function. Anesthesiology 2013, 118:1307-1321.

25. Futier E, Constantin JM, Paugam-Burtz C, Pascal J, Eurin M, Neuschwander A, Marret E, Beaussier M, Gutton C, Lefrant JY, Allaouchiche B, Verzilli D, Leone M, De Jong A, Bazin JE, Pereira B, Jaber S, IMPROVE Study Group: A trial of intraoperative low-tidal-volume ventilation in abdominal surgery. N Engl J Med 2013, 369:428-437.

26. Determann RM, Wolthuis EK, Choi G, Bresser P, Bernard A, Lutter R, Schultz MJ: Lung epithelial injury markers are not influenced by use of lower tidal volumes during elective surgery in patients without preexisting lung injury. Am J Physiol Lung Cell Mol Physiol 2008, 294:L344-L350.

27. Cai H, Gong H, Zhang L, Wang Y, Tian Y: Effect of low tidal volume ventilation on atelectasis in patients during general anesthesia: a computed tomographic scan. J Clin Anesth 2007, 19:125-129.

28. Sundar S, Novack V, Jervis K, Bender SP, Lerner A, Panzica P, Mahmood F, Malhotra A, Talmor D: Influence of low tidal volume ventilation on time to extubation in cardiac surgical patients. Anesthesiology 2011, 114:1102-1110.

29. Hemmes SN, Severgnini P, Jaber S, Canet J, Wrigge H, Hiersmayr M, Tschernko
EM, Hollman MW, Binnekade JM, Hedenstierna G, Putensen C, de Abreu MG, Pelosi P, Schultz MJ: Rationale and study design of PROVHILO a worldwide multicenter randomized controlled trial on protective ventilation during general anesthesia for open abdominal surgery. Trials 2011, 12:111.

30. Hemmes SN, de Abreu MG, Pelosi P, Schultz MJ: ESA Clinical Trials Network 2012: LAS VEGAS - Local assessment of ventilatory management during general anaesthesia for surgery and its effects on postoperative pulmonary complications: a prospective, observational, international, multicentre cohort study. Eur J Anaesthesio/ 2013, 30:205-207.

31. Lee PC, Helsmoortel CM, Cohn SM, Fink MP: Are low tidal volumes safe? Chest 1990, 97:430-434.

32. de Pinheiro Oliveira R, Hetzel MP, dos Anjos Silva M, Dallegrave D, Friedman G: Mechanical ventilation with high tidal volume induces inflammation in patients without lung disease. Crit Care 2010, 14:R39.

33. Determann RM, Royakkers A, Wolthuis EK, Vlaar AP, Choi G, Paulus F, Hofstra JJ, de Graaff MJ, Korevaar JC, Schultz MJ: Ventilation with lower tidal volumes as compared with conventional tidal volumes for patients without acute lung injury: a preventive randomized controlled trial. Crit Care 2010, 14:R1.

34. Bregeon F, Roch A, Delpierre S, Ghigo E, Autillo-Touati A, Kajikawa O, Martin TR, Pugin J, Portugal H, Auffray JP, Jammes Y: Conventional mechanical ventilation of healthy lungs induced pro-inflammatory cytokine gene transcription. Respir Physio/ Neurobio/ 2002, 132:191-203.

35. Gajic O, Dara SI, Mendez JL, Adesanya AO, Festic E, Caples SM, Rana R, St Sauver JL, Kymp JF, Afessa B, Hubmayr RD: Ventilator-associated lung injury in patients without acute lung injury at the onset of mechanical ventilation. Crit Care Med 2004, 32:1817-1824.

36. Yilmaz M, Keegan MT, Iscimen R, Afessa B, Buck CF, Hubmayr RD, Gajic O: Toward the prevention of acute lung injury: protocol-guided limitation of large tidal volume ventilation and inappropriate transfusion. Crit Care Med 2007, 35:1660-1666.

37. Wolthuis EK, Veelo DP, Choi G, Determann RM, Korevaar JC, Spronk PE, Kuiper MA, Schultz MJ: Mechanical ventilation with lower tidal volumes does not influence the prescription of opioids or sedatives. Crit Care 2007, 11:R77.

38. Serpa Neto A, Cardoso SO, Manetta JA, Pereira VG, Espósito DC, Pasqualucci Mde O, Damesceno MC, Schultz MJ: Association between use of lungprotective ventilation with lower tidal volumes and clinical outcomes among patients without acute respiratory distress syndrome: a metaanalysis. JAMA 2012, 308:1651-1659.

39. Licker M, Diaper J, Villiger Y, Spiliopoulos A, Licker V, Robert J, Tschopp JM: Impact of intraoperative lung-protective interventions in patients undergoing lung cancer surgery. Crit Care 2009, 13:R41

40. Hemmes SN, Serpa Neto A, Schultz MJ: Intraoperative ventilatory strategies to prevent postoperative pulmonary complications: a meta-analysis. Curr Opin Anaesthesio/ 2013, 26:126-133.

41. Fuller BM, Mohr NM, Drewry AM, Carpenter CR: Lower tidal volume at initiation of mechanical ventilation may reduce progression to acute respiratory distress syndrome: a systematic review. Crit Care 2013, 17:R11.

42. Peters JL, Sutton AJ, Jones DR, Abrams KR, Rushton L: Comparison of two methods to detect publication bias in meta-analysis. JAMA 2006, 295:676-680.

43. Michelet P, D'Journo XB, Roch A, Doddoli C, Marin V, Papazian L, Decamps I, Bregeon F, Thomas P, Auffray JP:Protective ventilation influences systemic inflammation after esophagectomy: a randomized controlled study. Anesthesiology 2006, 105:911-919.

44. Mascia L, Bosma K, Pasero D, Galli T, Cortese G, Donadio P, Bosco R: Ventilatory and hemodynamic management of potential organ donors: an observational survey. Crit Care Med 2006, 34:321-327.

45. Mascia L, Pasero D, Slutsky AS, Arguis MJ, Berardino M, Grasso S, Munari M, Boifava S, Cornara G, Della Corte F, Vivaldi N, Malacarne P, Del Gaudio P, Livigni S, Zavala E, Filippini C, Martin EL, Donadio PP, Mastromauro I, Ranierir VM: Effect of a lung protective strategy for organ donors on eligibility and availability of lungs for transplantation: a randomized controlled trial. JAMA 2010, 304:2620-2627.

46. Lin WQ, Lu XY, Cao LH, Wen LL, Bai XH, Zhong ZJ: Effects of the lung protective ventilatory strategy on proinflammatory cytokine release during one-lung ventilation. Ai Zheng 2008, 27:870-873.

47. Yang M, Ahn HJ, Kim K, Kim JA, Yi CA, Kim MJ, Kim HJ: Does a protective ventilation strategy reduce the risk of pulmonary complications after lung cancer surgery?: a randomized controlled trial. Chest 2011, 139:530-537.

48. Pelosi P, Croci M, Ravagnan I, Tredici S, Pedoto A, Lissoni A, Gattinoni: 
The effects of body mass on lung volumes, respiratory mechanics, and gas exchange during general anesthesia. Anesth Analg 1998, 87:654-660.

49. Pelosi P, Gregoretti C: Perioperative management of obese patients. Best Pract Res Clin Anaesthesio/ 2010, 24:211-225. doi:10.1186/cc13778

Cite this article as: Sutherasan $Y$, et al:: Protective mechanical ventilation in the non-injured lung: review and meta-analysis. Critical Care 2014, 18:211. 